\title{
A BRIEF GLANCE AT RACIAL DISCRIMINATION*
}

\author{
Professor Dr. Türkkaya ATAÖV
}

Scientists have reached general agreement in recognizing that mankind is one. Differences as exist between various groups are due to the evolutionary factors of differentiation such as isolation. A race is a group which in the past was more or less separated by virtue of the isolating barriers and which exhibits certain attributes as a result of a varying biological history.

However, when some people use the term "race", they refer to any group of people whom they choose to describe as such. National, religious, linguistic and cultural groups do not necessarily coincide with racial groups. Most anthropologists divide the majority of present-day mankind into three principal parts, the Caucasoid, the Negroid and the Mongoloid. Many sub-groups may be described within these divisions. The tests have shown that, given similar degrees of opportunity, the average achievement of the members of each ethnic group is about the same.

Article 1 of the International Convention on the Elimination of All Forms of Racial Discrimination describes the term "racial discrimination" to mean "any distinction, exclusion, restriction or preference based on race, colour, descent, or national or ethnic origin which has the purpose or effect of nullifying or impairing the recognition, enjoyment or exercise, on an equal footing, of human rights and fundamental freedoms in the political, economic, social, cultural or any other field of public life."

Further, Article 2, Paragraph 2 of the UNESCO Declaration on Race and Racial Prejudice describes racism as including "racist ideologies, prejudiced attitudes, discriminatory behaviour, structural arrangements and institutionalized practices resulting in racial inequality as well as the fallacious notion that discriminatory relations between groups are morally and scientifically justifiable". It divides nations internally, gives rise to political tensions between peoples, hinders the development of its victims, corrupts those who practise it and seriously disturbs international peace and security.

\footnotetext{
"Submitted to the "Anti-Racist International Conference", 1988, Sweden.
} 
Racism and racial discrimination figure among the most explosive phenomena of our times. They are practiced today against millions of people apparently for the simple reason that they differ in the colour of their skin and/or national, ethnic or religious origins. Some people, for instance, the natives of North and South America, Australia and Northern Europe have much less right than others. The illegitimate minority government in Southern Africa deprives the people of Azania and Namibia of basic human rights, including that of self-determination. Elsewhere, there are numerous minorities discriminated against. But the example of Palestine shows basic rights being denied even to whole peoples.

Racism and racial discrimination have always been instruments of oppression and justification for exploitation. Underlying discrimination are deep socio-economic roots, involving a conflict for division of wealth and of political power. The European monopolistic bourgeoisie and imperialism have utilized racism to advocate the superiority of certain races and thus "prove right" colonial tyranny. The Nazi régime killed millions on that very pretext. Events soon proved that the racism of Nazi Germany could not be confined to a single country and that racism by its very nature was a threat to international peace as well.

$$
\text { * }
$$

The present confrontations around racism and racial discrimination have also acquired serious proportions. But since the overwhelming majority of mankind now realizes that the evil of racism threatens to erupt into armed conflicts, this issue has international dimensions much more than ever.

One may identify a number of institutionalized or de facto, overt or subtle situations of discrimination. But apartheid is the most pernicious and organized form of racism. It is a crime against humanity under the International Convention on the Suppression and Punishment of the Crime of Apartheid adopted by the Uni^ed Nations General Assembly (1973). It is well known that U.N.'s concern with the racist policies of the apartheid régime is of long standing. But since 1960, with the first wave of the newly-independent states of Africa joining the U.N., response of this international organization to the gross violations of human rights has undergone quantitative changes. The U.N. has moved from general to specific resolutions requesting member states to take actions against the white minority dictatorship. The resolutions now deal with a variety of topics, from relations between South Africa and Israel or oil embargo to political prisoners or apartheid in sports. 
By now, many know the basic facts: The non-Europeans living in the Republic of South Africa outnumber the Europeans five and one-half to one. The whites are in the minority in all the provinces. Although so small in number, the Europeans possess over $80 \%$ of the land. In spite of the drive to congregate the blacks in the so-called "Bantu homelands", more Africans live outside them. Not only in the rural, but also in the urban areas, the Africans constitute the majority.

South Africa is a state adapted to secure the supremacy of the white minority. Apartheid operates as racial discrimination, economic exploitation and police terror. Racial discrimination does not only connote an attitude; it is an act which denies equality and sharpens stratification. it relies on several acts denying Africans various rights, from ownership of land to the use of public buildings. Economic exploitation of natural and human resources serves apartheid in terms of increasing the wealth of the white minority, capitalizing on cheap African labour and attracting foreign investment to maintain racial supremacy. These objectives also have their own instruments, compelling the Africans to accept employment or prohibiting mixed trade unions. Police terror is inseparable from apartheid. Among its instruments are various acts which define "sabotage", "terrorism" and "communism".

The Africans, Coloureds and Asians are of course the major targets of apartheid. But it mainly rests on the shoulders of the Africans - and especially the African workers. It should always be borne in mind that apartheid essentially exists to control African labour, which is the key to South Africa's economic development. Racism is, after all, the political institution of an economic mechanism of extracting huge profits from the labour of the black man. Central to the exploitation of the African workers are the pass laws. The African workers require permission to work, to travel and to stay in urban areas. The pass laws also curtail the ireedom to organize. And in dealing with workers, the South African Government does not rely on laws only. It is now common knowledge that they are subjected to police brutality. The racist régime of Pretoria continues repressions, arrests, massacres and executions. Detentions and interrogations frequently end in death. Among many victims was Steve Bantu Biko, Honorary President of the Black People's Convention and founder of the black consciousness movement in South Africa. Apart from hundreds sentenced to several years, there are political prisoners serving life sentences. Nelson Mandela is among them.

The Republic of South Africa is trying to administer Namibia as if it was still a League of Nations Mandate. This is an illegal and repressive 
occupation. The international community has assumed a solemn obligation to enable the Namibian people to exercise their inalienable right to selfdetermination and national independence. Colonized Namibia's economy is characterized by two prominent features: (a) the extensive foreign extraction of the country's varied natural resources, and (b) a subsistence agriculture enveloping the majority of the African population, forced to live in the Bantustans. This is the central dynamics of economic exploitation under the South African occupation. As the colonial power, the South African régime has structured the economy of the country according to the interests which it serves: in the first place, South African based capital and foreign based capital. The local settlers are subordinated to these interests as junior partners in exploitation. The South Africans have also subordinated the surviving pocket:s of the peasant economy of the Namibian people to their central design: namely, the building of a system of exploitation based on cheap wage labour. The peasant impoverishment forces them to work for very low wages, and the rural reserve army of labour is used, together with totalitarian labour controls, to keep the wages at starvation levels. For the foreigners this system guarantees exorbitant profits, and for the colonial régime it is a source of revenue and a corrective to South Africa's trade deficit.

Three export sectors, that is mining, fishing and farming, account for nearly all commercial primary production in Namibia. That country is rich in mineral resources in demand throughout the industrial economies of the Western world. The coastal sands of the Southern Namib cover extensive fields of diamonds. On the central plateau, a large variety of base mineral ore bodies are located, notably copper, lead, zinc and coal. Inland, the Namib holds vast reserves of low-grade uranium. Prospecting has shown that the Walvis Ridge is potentially rich in supplies of oil and natural gas.

With a population of 1.6 million, Namibia has one of the highest per capita incomes in Africa. It also has one of the world's most skew.ed income distribution patterns. It provides a lucrative, captive market to South Africa. The most pronounced attempt to preserve Namibia's natural lesources came in 1974 when the U.N. Council for Namibia enacted Decree No. 1 for the Protection of the Natural Resources of Namibia against further usurpation by the apartheid régime and its allies. The U.N., governments, NGOs and parliamentarians should be urged to take further steps to enforce Decree No. 1. Such steps may include (a) pressure on governments which have not recognized the legal validity of the Decree to do so; (b) research into violations of the Decree; (c) international coordination to support actions taken against violations (such as the 
Liverpool port workers' refusal to handle shipments of Namibian uranium) and (d) direct action against companies involved in illegal prospecting.

SWAPO is the organizational expression of the Namibian people. It is their means of attaining justice. Misappreciation of this fact is the dilemma of the racists. Denial of a SWAPO government leads to a dead end. There is no other workable alternative. To prolongate the inevitable is tragic, because it is pointless. Parliamentary maneouvres like the Turnhulle Conference are total farces. The whites are caught in their racism. Just as there is no alternative to Namibian independence, there is no alternative to a SWAPO government. The two are organically linked.

The question of Namibia is an issue in itself. It is a matter of decolonization, and it should not be presented in an East-West context.

\section{$*$}

The black people, who have made a large contribution to the development of the United States of America, are also discriminated against in that country. The struggle by the Afro-Americans against slavery and racial discriminaton has written many. glorious pages in the history of the best traditions of the American people. However, the cruelest ciscrimination against the Blacks remains the most complex socio-economic, political and legal problem of the United States.

The struggle of the Black Americans for their rights, not only caused significant progress in solving problems vitally important to them, but also helped to democratize the nation's domestic policies as a whole. The first American Revolution led to the abolition of slavery in the North. The second one was marked by the abolition of slavery on a nation-wide scale. And the rapid rise of the Afro-American movement in the 1960s led to the elimination of the more crude forms of racial discrimination.

But even today, there are strong racial prejudices in the United States. All through American history, Blacks have been treated as secondrate people. These racist traditions affect a portion of the whites even today. Civil right statutes are good in themselves, but they cannot create jobs or build houses. Anti-discrimination laws, if administered forcefully, can control conduct and affect attitudes. But racism dies hard. Merely declaring discrimination on the ground of race or colour illegal cannot overcome the prejudice, emanating from self-interest of an entrenched majority. An unenforcable declaration, without penalty, is only a token gesture. Similarly, when institutions implement racist policies, what is being destroyed is not only the lives of some Black citizens, but also the hope that progressive change in the society is possible. Only the combined 
efforts of the Whites and the Blacks will bring forth a better American commonwealth.

The so-called American "Indians", the Puerto Ricans, the Haitians, the peoples of the Far East and of the Pacific Islands also face discrimination. The "Indians", who are the original inhabitants of America, suffer from a series of problems stemming from their historical and current relationship with the Whites. Their population has been reduced by war and disease to less than one-tenth of its probable pre-Columbian level. Today, the majority are very poor. Unemployment runs at around $40 \%$, and $18 \%$ of those employed have only temporary or seasonal jobs. $90 \%$ of their housing is sub-standard. They consider the Bureau of Indian Affairs as an oppressive institution and unresponsive to their wishes.

Puerto Rico has an unemployment rate of $30-40 \%$. Thousands migrate north each year. Soon, half of the Puerto Rican population will live in the United States. And half of those living in the United States will have been born there. The Haitians suffer widespread discrimination. They have the highest unemployment rate of any group in the United States.

Elsewhere, aborigines either face extinction or are markedly kept in an inferior position. For instance; about a million and a half aboriginal people of Canada. once owned all of that wide country: Now, the Indian, Inuit and Metis are being extinguished. The official attitudes of Australian Governments towards the aborigines, constituting about $1 \%$ of the total population, have historically undergone many changes. The breakthrough came with the election of a Labour Government under G. Whitlam (1972). Although that government aimed at outlawing racial discrimination, all indicators such as unemployment, infant mortality and life expectancy show that the aborigines are kept in an inferior situation.

The continent of Europe is full of various kinds of minorities, some of which suffer discrimination. The treatment of the Swedish population of Finland is generally considered as the best treatment of a minority. Swedes see themselves as "co-founders" of the Finnish state. This attitude is also adopted by the Turkish Cypriots and the French Canadians in respect to Cyprus and Canada. The Sami, that is, the indigenous inhabitants of the far north of Europe, traditionally known as Lapps, are divided politically between Norway, Sweden, Finland and the U.S.S.R. The Sami, who are among the world's least numerically strong minorities, are distinct from the Indo-European language grouping, which includes most of the Europeans. They belong to the Finno-Ugrian ethnic 
group, believed to be of Asian origin. The Sami have been subjected to centuries of pressure and to the temptations of assimilation. Their physical environment, which is vital to them, is being assaulted. Amongst both Catalans and Basques, there is widespread sense of belonging to oppressed national groupings. Their demands contributed to the collapse of the Spanish Republic in the 1930s. They can threaten Spain's political stability even now. There is a political, religious and social conflict that lies beneath the rioting, deaths and material damage connected with the Irish question.

These and other minorities claim discrimination against themselves in particular regions of Europe. The Rom (Gypsies), on the other hand, are a rejected minority in almost the whole of the continent. The first Rom having entered Western Europe in the Middle Ages, they are the first "blacks" in that continent. To the Medieval mind, Rom, coming from the Turkish side of Europe and beyond, were suspect. Up unitil the last century, they were called heiden (heathens) in Holland. The Church, the state and the guilds opposed them. They were exploited in Scottish mines or served as serfs in Rumania. Having tried banishment, some European countries transported them to their colonies in North and South America and Australia. Later, Nazi Germany chose genocide, during which perhaps half a million perished.

Those who escaped the blood-bath of the "final solution", still faced the prejudice of the post-war Europe. Some states simply closed their frontiers to foreign Rom and deported those who do not have citizenship. Before referring briefly to the post-war circumstances, one should exempt some countries from criticism. Yugoslavia, which hosts perhaps half a million Rom, assists this minority. The Netherlands provided caravan sites for its Rom. Britain imitates this procedure, at a slower pace. Sweden showed willingness to house a thousand Rom, previously living in the Stockholm slums.

But the French laws discriminate against them. The police tightly controls their lives. One frequently runs into signs that say "Interdit aux Gitanes". There were instances when their huts were demolished, animals slaughtered or their personal property set on fire. The 1972 Law prohibits door-to-door sales, which threatened the livelihood of many Rom. Encampments were also set on fire in Italy, Ireland and Spain. In Belgium, families are not allowed to stay more than a day and a night at the roadside, which prevents children from attending school. In West Germany, they have difficulty in finding a place to pull up for the night. Switzerland closed its frontiers even to Rom attending the 1965 pilgrimage tc Rome. 
More serious than that, some 730 Rom children have been imprisoned in institutions and kept away from their parents. They were told that their parents had died. Upon reaching the age of 18, some Rom girls were sterilised. The Council of Europe recommended that the states take all steps necessary to stop discrimination in legislation and in administrative practice. These recommendations were ignored in a number of European countries.

Some of the European minorities, such as the Hungarians of Rumania, ine Turks of Bulgaria, the Macedonians and the Crimean Tatars, have lately been on the headlines. As a result of the disintegration of the old Kingdom of Hungary (1918-20)), somewhere over three million ethnic Hungarians (Magyars) were assigned to the successor states. The provisions of the Paris Peace Conference (1919) were confirmed by the Peace Treaties 1947) after the Second World War. Rumania, Czechoslovakia and Yugoslavia plus the Soviet Union, to which was added Subcarpathian Ruthenia (from Czechoslovakia) and therefore a small number of Hungarians, retained their sovereignty over about one-third of the Hungarian nation. The largest single group of Hungarians outside the Hungarian state is in Transylvania, a Western part of Rumania. It is also numerically the largest minority in Europe. The total population of Transylvania is about 7 million, the majority of which is Rumanian. The bulk of the rest is Hungarian (less than 2 million.) There are smaller minorities of Germans $(400,000)$, Serbs, Ukranians, Slovaks, Czecks, Bulgarians, Armenians and Gypsies. The Szeklers are an ethnologically distinct people, but have to be considered with the Hungarian national group. Just as the Hungarian state believes that in has a certain locus standi vis-a-vis the Hungarians oit Transylvania, so the Rumanian state claims a similar status in respect to the Rumanians of Bessarabia, the Moldavian S.S.R. in the Soviet Union.

The Bulgarian Government asserts that, some time between 1984 and 1985 , its Moslem population "voluntarily and collectively" chose to change its Turkish-Moslem names to Bulgarian-Slavic ones and it has likewise decided to abandon a number of Turkish-Moslem customs and rituals. On the other hand, the history of the Balkans during the Ottoman period as well as several bilateral and international treaties indicate that there have always been Moslem Turks living in Bulgaria since the Fourteenth Century. Some of these international instruments that clearly refer to the Moslem Turks also bear the signature of Bulgaria. The Turks of Bulgaria are citizens of that country but of Turkish descent whose mother tongue is Turkish and whose religion is Islam, with cultural characteristics peculiar to themselves. 
The Macedonians of today are not, as some think, descendants of the long since vanished Macedonians of Alexander the Great. They are Slavs, who speak a language related to the Serbo-Croatian and the Bulgarian. They came from the Russo-Polish-Ukrainian plains in the Sixth and Seventh Centuries A.D. and settled in the Balkans. And only at the middle of the Twentieth Century, after the Second World War, did they form their own national state, called "Macedonia", within federated Yugoslavia. There are Macedonians in Bulgaria and Greece as well, where they are considered Bulgarian and Greek, respectively. But it is impossible to be an ethnic Bulgarian and an ethnic Greek at the same time.

The Crimean Tatars, the Soviet (including the Volga) Germans and the Meskhetians are distinguishable from the numerous other national groups in the U.S.S.R., in the sense that, unlike several other nationalities deported en bloc from the European part of the Soviet Union to Siberia and Central Asia during the Second World War, these three have still not been allowed to return to their former homes.

The Crimean Tatars were deported from the Crimea on 18 May 1944 for alleged wholesale collaboration with the Germans. Today, they mainly live in Uzbekistan. They were politically rehabilitated, that is, absolved of the charge of wholesale collaboration in late 1967. The confrontation between Russia and the Crimean Tatars dates back to the Mongol Tatar invasion of Europe. The Crimean Tatars, a Moslem Turkic people, are descendants of the Golden Horde and also the Turkic tribes who came before the Mongols. With the disintegration of the Golden Horde, a separate khanate in the Crimea, had come into being. From the second half of the 17th Century, Russia began to gain ascendancy, and Russian troops invaded the Crimea. The final straw was the recognition of the Ottoman Empire of Russian annexation (1792), depriving the Tatars of hope to regain their independence. With the establishment of Soviet rule there in late 1920, the Crimean Autonomous S.S.R. was formally set up on 18 October 1921 as part of the R.S.F.S.R. The early years of the Crimean A.S.S.R. have been described as the "Golden Age" of the Crimean Tatars under Soviet rule. But with the approach of the Second World War, Stalin's suspicions concerning the loyalty of some of the non--Russian subjects became immense. However, during the war, large numbers of Crimean Tatars, like citizens of various other nationalities, served loyally in the Red Army or fought with the local partisans. Some Tatars, many of whom were prisoners of war, fought against the Soviet detachments. There were other Soviet citizens, including Russians, who served in the German armed forces. But the Soviet press at the time carried reports of Tatar heroism, and more than a dozen of them were given the highest 
award for bravery. After the Red Army offensive in the Crimea, the Tatars who had collaborated with the Germans were immeailately sentenced to death. But before dawn on 18 May 1944, six days after the last German had left Crimean soil, all the remaining Tatars were roused from their beds, some given about fifteen minutes to collect their belongings and taken to Central Asia and elsewhere. There was a high death toll during the journey and the following eighteen months. Back in the Crimea the confiscated property of the Crimean Tatars was given to the Ukrainian settlers. Old Tatar place names were replaced by Russian ones. The autonomous republic was abolished, and the history of the Crimea was re-written, omitting reference to the cultural achievements of the Crimean khanate and its suffering under the Tsars. The Crimean Tatars want to "eturn home. For them, the lack of national autonomy means deprival of the conditions necessary to preserve national identity.

$$
\text { s. }
$$

The foreign workers in Europe, who are now the continent's "reserve army" of new proletarians, are targets of various forms of discrimination. Every seventh man in Europe is a foreign worker. Adding together all the migrant workers, one reaches a figure half as many as emigrated from Europe to North America in the general migrations of the 19th and the 20 th Centuries. Yet this new migration occurred in only 35 years. Millions of foreign workers have been living in Western Europe for the past three decades to meet the growing demand for work from industries and services. They came northwards mainly from Greece, Italy, Portugal, Spain, Turkey and Yugoslavia. They came, especially to France, from North Western Africa and the former French colonies in West Africa. They came to the U.K. from India, Pakistan and the West Indies. They came to the

- Netherlands from Surinam, the Antilles and Indonesia, all former Dutch colonies.

In Switzerland, over 1 million foreigners constitute about $17 \%$ of the population and over $25 \%$ of the labour force. The Federal Republic of Germany, France and the U.K. each has about four million immigrants making $5-10 \%$ of the total population. In Belgium, Holland and Sweden, there are substantial numbers of immigrants. Some have also gone to Austria and Danemark. The figure of some 15 million or more does not show the full number of people affected by migration. Millions more came for short periods and returned home. No quarter knows accurately the total of how many workers and their families came. Each country uses different definitions and collects its figures in different ways. For instance, in Holland, statistics on the foreign population are issued by three departments - the Central Bureau of Statistics, the Ministry of Justice and 
the Ministry of Social Welfare. They all give different numbers. And many Surinamese and Antillese immigrants possess Dutch passports and do not figure in the statistics of immigrants. There are also illegal immigrants working in Europe.

The massive migrations of Turks to the F.R. of Germany, Italians to Switzerland, Algerians to France, Moroccans to Belgium and Surinamese to the Netherlands were closely correlated with economic growth in the host country. Immigrants are now rooted in the European economy. They are no longer a handful of foreigners, who stayed to earn a certain "target income". Although some went back, the majority stayed on, bringing over first the wife and then the children, who started to go to school.

In the F.R. of Germany, they are called Gastarbeiter, guest workers, implying that they are there at the behest of the hosts. Ganzunter, the best-selling book by Günter Wallraff, a German journalist who temporarily adopted a typical Turkish name (Ali Levent) and worked in several German enterprises, posing as a Turkish worker, drew European attention, not only to the plight of the Turkish working people, but also to all foreign migrants in Europe. Frequently bringing to mind Upton Sinclair's classic, The Jungle, which also dwelled on the conditions of work in Chicago, Wallraff's book in German sold two million copies in the first four months and was translated into a dozen languages.

The question of the rights of foreign workers appears to be largely unresolved. Not only the rights are legally limited, the confusion caused by conflicting policies works against them. Ambiguities in laws and policies provide openings for discrimination. Foreign workers are far from having the rights of citizenship. Generally, work-place participation is greater than political participation. Even there, it is not direct by the rank-and-file foreigner, but rather the extent to which unions are pressured to represent their interests as well. In-countries where there is such indirect representation, direct voice as well may be demanded. Sweden and the Netherlands gave resident foreigners the right to vote in municipal elections in the late 1970s.

Some foreign workers attempted to be active in political parties, but they brought forth more fear and hostility than understanding and cooperation. A considerable portion of the Europeans seem to be unable to decide on the formulation of the problem that they are facing. Do they favour isolation, integration, assimilation or out-migration? Each of these choices need a different answer. A German solution such as the encouragement of out-migration through monetary incentives assume a "Germany for the Germans" approach. Belgian laws make them feel that if they 
organized and protest too much, they would be out. Indeed, the Belgian Ministry of Justice has almost unlimited powers to order a foreigner to leave. In Switzerland, the labour unions are weak and do not provide help to immigrant workers.

The inflow of migrants has aroused antagonism from substantial segments of the population. The prevalence of hostility to all immigrants and of racial prejudice against specific groups has been well-documented. Hostility is expressed in a variety of ways. The Dutch have burned down several immigrant lodging houses. There have been repeated attacks in France. Less dramatic incidents of racism and discrimination are common. For example, some Belgian shops, during the 1973 oil crisis, refused to sell bottled gas to North Africans, telling them that the crisis was their fault as Arabs. There are endless examples of discrimination in housing.

The political reflection of growing anti-immigration reactions was first the growth of extremist organizations and then political parties for which opposition to the immigrants was either the only or the main issue.

Generalizations for the Gulf, however, are difficult since there are so many foreigners working there at so many different levels. It is wellknown that the 1973 oil price explosion and the increase in revenues caused a massive wave of labour by the Turks, the Iranians, the Afghanis, the Indonesians, the Malaysians, the Philipinos, the South Koreans, the Thais and the rest originating from parts of Africa, Europe and the Americas. By 1980, Kuwait had employed workers from 68 different countries. Althought it is difficult to make generalizations, one can say that most of the foreign workers in the Gulf suffer from lack of protection due to absence of well-defined legal rights. They have only a few privileges enjoyed by local nationals.

A discussion of the living conditions of the Gulf worker brings us to an outstanding topic of discrimination in the same area - the Palestinians. The Proclamation of Independence of Israel contains the following words: "[The State of Israel] will maintain complete equality of social and political rights of all citizens, without distinction of creed, race or sex..." Although this declaration proclaims equal rights, it has no legal force. Fundamental laws, which mandate preferential treatment for Jews, contradict that declaration. The indigenous Palestinian Arabs in Israel are fourth-class citizens after the European, Oriental and Black Jews.

Zionism requires two related processes, namely the separation of the Jews from their respective countries, with the consequence of their transplantation on a different soil and also the removal of the non-Jews 
from the same land. This inter-related process involves, first of all, the inhuman transfer of the Palestinians. Beginning with the Deir Yassin massacre of 1948 , the indigenous population was forced to abandon their homes and lands in great numbers. In addition to mass depopulation, Israel also frequently resorted to individual deportations, particularly of intellectuals. Fawaz Turki and others painted moving pictures of the tormented Palestinian living in exile. The Palestinian is still considered an alien, an outsider, a refugee, a burden.

In Israel, there is no law which makes discrimination illegal. Israel is and wants to stay a "Jewish state". This means that the majority should always be Jewish. And to protect the Jewish majority, the Palestinian Arabs, Moslem or Christian, must remain refugees. Those Palestinians who remained on their land are also discriminated against in various ways, both in law and practice. The "Koenig Report", intending to analyze the situation of the Arabs in Israel and pretending to suggest ways to handle them, is illuminating in this respect. It was written by Israel Koenig, who was the "District Commissioner for the North", that is the official responsible for putting into effect the policies of the Israeli Ministry of the Interior in the Galilee district, where most of the Arabs live. The report and its author have become symbols to a chauvinist spirit which concludes a priori that there is little place for Arabs in the society, that they are a potential threat, and therefore must be treated like secondclass citizens.

To begin with, there is effective discrimination against Arab political representation. The bureaucracy of the Israeli state has resorted to several means to prevent genuine Arap representation in the Knesset. Israel makes use of the Defence (Emergency) Regulations of 1936, inherited from the British Mandate, to suppress the freedoms of the Arab population. When these Regulations were introduced before the Second World War, they were violently critized by the Jewish community in Palestine. It is the same laws that are operative today.

The laws of 1953,1961, 1967 and other acts prohibit the sale and leasing of land to non-Jews. There are no laws forbidding the sale or lease of land owned by non-Jews to Jews. Territory now classified as the Jewish National Land is vast tracts of land confiscated from the Arabs. The Jewish National Fund reserves only a limited amount of the credit for the land appropriated; the largest share goes to military conquest. It is also forbidden to use Arab labour on Jewish National Land. There is a general discrimination of employment in Israel. The privileged European Jew has a virtual monopoly over the highest paid jobs. The Arabs are not employed in positions which have, by any stretch of 
imagination, a connection with national security. They cannot be seen in any official post supervising Jews. Housing and education facilities are also based on discrimination. While Arab houses are blown up, whole Arab quarters demolished and Arab villages destroyed, better apartments are traditionally inhabited by the European Jews. More Arab lands are expropriated as new Jewish settlements in the annexed territories are set up. Arab children are enjoying less than equal access to educational opportunities. The Arabs represent less than one percent of the total enrollment in the universities and the other institutions of higher learning.

The condition in territories occupied after the 1967 aggression are even more alarming. Israel is flagrantly violating several international instruments. A basic argument on which the Nazis based their defence was that there had been no international convention sufficiently protecting civilian populations during the war. The Jews were, then, among the victims. A conference was convened in Geneva (1949) so that the same crimes could not be repeated. Israel participated in it, it signed (1949) and ratified (1951) it. However, Israel habitually violates this Convention, specifically formulated to prevent the repetition of crimes of which the Jews were the victims.

Israel now occupies territories that belong to three neighbouring Arab states. The occupied Syrian and Egyptian territories are outside the boundary of the Palestine Mandate. Gaza and the West Bank fall outside the frontiers ascribed by the 1949 General Armistice Agreements. A territory is occupied when it is actually placed under the authority of a hostile army. It is apparent that the Golan Heights, the West Bank and the Gaza are all occupied territories, and their inhabitants are protected persons within the meaning of the Hague and the Geneva Conventions. The settlement of the Israeli citizens in the occupied territories, the prevention of the refugees from going back to their homes, mass arrests and several acts of intimidation are all violations of the above-mentioned international agreements.

Reports on arrests and torture are especially shocking. They are documented by the U.N., the Israeli League for Human and Civil Rights, Amnesty International and the International Red Cross.

Racism and racial discrimination have ceased to be questions of domestic jurisdiction. They are the kind of policies that lead to violent conflicts, creating crises which constitute a grave threat to international peace and security as well. The peoples of the world have a right to demand that racist laws be annulled and discrimination be eradicated from the surface of the earth. 